\title{
Growth Pattern of School Going Children with Asthma: A Case Control Study
}

\author{
Jayasree $\mathbf{P}^{1}$ \\ ${ }^{1}$ Professor, Department of Paediatrics, Mount Zion Medical College, Adoor, Kerala.
}

\section{Abstract}

Background: To compare growth pattern of children with asthma against healthy controls and to assess the quality of life score in children with asthma. Subjects and Methods: The study was conducted in the outpatient and inpatient departments of Department of Pediatrics amongChildren between 5-15 years with clinical diagnosis of asthma were enrolled in this study. It was a cross sectional study. Results: Our study included 100 children between 5 - 10 years age group which had 50 children having asthma and rest were normal children. Out of 50 asthma children, $5(10 \%)$ had obesity and study was significant ( $\mathrm{p}=0.028)$. And 20 of the 50 asthma children $(40 \%)$ had stunting.( $\mathrm{p}=0.015)$. In 11 to 15 years age group $4(8 \%)$ had obesity $(\mathrm{p}=0.072)$ and $24 \%$ had stunting and the study was significant $(\mathrm{p}=0.029)$. Conclusion: Stunting and obesity are more seen in children with asthma compared to normal children. Children with severe forms of asthma and children were whose asthma was poorly controlled were more prone for stunting and obesity.

Keywords: Asthma, QOL(Quality of life), BMI, Stunting, Obesity.

Corresponding Author: Dr. Jayasree P, Professor, Department of Paediatrics, Mount Zion Medical College,Adoor, Kerala.

Received: February 2019

Accepted: February 2019

\section{Introduction}

Asthma is a chronic inflammatory disorder of the airways in which many cells and cellular events play a role. It is associated with airway hyper responsiveness that leads to recurrent episodes of breathlessness, wheezing, chest tightness and coughing particularly in the night or early morning. [1]

Children suffering from asthma can show growth retardation both in height and maturation. It has been further suggested that the retarded bone age of most children with severe asthma indicates that they will tend to mature late and will ultimately grow to a normal height. ${ }^{[2]}$ The purpose of this study is to study the growth variables (height, weight, and body mass index) of children with asthma in the age range of 5-15 years. ${ }^{[3]}$

Obesity has been shown to be a risk factor for asthma. Obesity is defined as body mass index of $>95$ th centile as per CDC growth chart. Obesity is associated with large number of changes in physiology that may mediate the relation between obesity and asthma. Adipose tissue is associated withincrease in pro-inflammatory cytokines and chemokines such as tumor necrosis factor-a (TNF-a), interleukin-6 (IL-6), plasminogen activator inhibitor-1 (PAI1), macrophage chemotactic protein- 1 (MCP-1), and complement, which is increased in obese children. The effects of obesity may also be mediated by changes in the airway function since obesity and weight change have prospectively been associated with bronchial hyper responsiveness in asthmatic children as well as non- asthmatic children25. The combined effect of bronchial hyper responsiveness and pro inflammatory milieu in obese children may set a stage in onset of asthma. ${ }^{[4,5]}$

This idea broadened particularly with the introduction and widespread acceptance of the World Health Organization's definition of health as being more than the absence of disease; rather it encompasses physical, social and psychological dimensions of health. These three aspects became the major domains of the many measures of healthrelated quality of life (HRQL) that have been developed Patrecia Gomez De Souza et al, ${ }^{[6]}$ study done in Rio de Janerio, Brazil showed Emotional and activity limitation were most severely affected domain in quality of life of children with asthma.

\section{Subjects and Methods}

Clinical diagnosis of asthma was defined as more than three episodes of wheezing requiring bronchodilator therapy with or without corticosteroids in the past after the age of 5years. Asthma cases were further divided into newly diagnosed cases and old cases. For newly diagnosed cases, patients were classified as having intermittent, mild persistent, moderate persistent and severe persistent asthma according to the guidelines given by Global Initiative of Asthma (GINA)[1]. Intermittent and mild persistent were considered together as mild asthma in the present study. Those children who were already on any kind of controller medication were designated as 'old' cases and classified according to treatment response into well controlled, partially controlled 
$\&$ poorly controlled cases.

Age wise they were classified into two groups- 5-10 years and 11-15years.In each age group, 50 cases and 50 controls were aimed at. For each enrolled patient with asthma, detailed physical examination was conducted including the weight and height. BMI was derived using the formula weight in $\mathrm{kg} /$ (height in metre)2.CDC charts were used in measuring malnutrition, stunting and obesity. The values below 3rd percentile according to the standard CDC growth chart was considered as malnutrition, stunting and thinness respectively for weight, height and BMI. Obesity also can be detected by BMI (defined as >95th percentile). For statistical analysis Chi Square test will be used.

\section{Results}

Out of 100 asthma cases in my study including both 5 to 10 years and 11-15 years age group ,56 were female and 44 were male with $\mathrm{M}: \mathrm{F}$ ratio of $1: 1.27$

Our study included 100 children between 5 - 10 years age group which had 50 children having asthma and rest were normal children . Out of 50 asthma children, 5 (10\%)had obesity as compared to 50 normal children in which none were obese and study was significant $(\mathrm{p}=0.028)$. And 20 of the 50 asthma children(40\%) had stunting as compared to 9 out of 50 normal children(18\%) and the study was also significant.(p=0.015). In11 to 15 years age group, out of 50 asthma children, $4(8 \%)$ had obesity as compared to 50 normal children in which none were obese and study was not significant $(\mathrm{p}=0.072)$. And 12 of the 50 asthma children(24\%) had stunting as compared to 4 out of 50 normal children(8\%) and the study was significant $(\mathrm{p}=0.029)$. Out of 100 asthma cases including 5-10 year age group and 11-15 year age group, 46 cases were newly diagnosed asthma cases and they were classified into mild persistent, moderate persistent and severe persistent asthma as per GINA guidelines. 3 out of $11(27.3 \%)$ severe persistent asthma were above 95th centile and none of moderate asthma children were obese $(p=0.013)$ showing that severe persistent asthma children were more obese compared to mild to moderate persistent asthma. 6 out of 11 (54.5\%)severe persistent asthma had stunting as compared to 5 of $17(29.4 \%)$ moderate asthma children and 1 of 18 mild persistent asthma children (5.6\%) with( $\mathrm{p}=0.013)$ showing that severe persistent asthma children had more stunting compared to mild to moderate persistent asthma. In our study of 54 already diagnosed asthma cases on treatment, were divided into well controlled, partial controlled and poorly controlled. There were 30 out of $54(56 \%)$ were well controlled, 8 out of 54(14\%) were partial controlled and $16(30 \%)$ were poorly controlled. Out of which 6 out of $16(37.5 \%)$ poorly controlled asthma children had BMI above 95th centile and 11 out of $16(68.7 \%)$ had stunting with $\mathrm{p}=0.006$ and $\mathrm{p}=0.002$ respectively concluding that obesity and stunting were more associated with poorly controlled asthma.

Out of 100 asthma cases in the study, 56 were female and 44 were male with $\mathrm{M}$ : F ratio of 1:1.27.

Table 1: Sex distribution of children with asthma enrolled in the study.

\begin{tabular}{|l|l|l|}
\hline \multicolumn{2}{|l|}{ Asthma cases(n=100) } \\
\hline Sex & No: & $\%$ \\
\hline Male & 44 & 44 \\
\hline Female & 56 & 56 \\
\hline Total & 100 & 100 \\
\hline
\end{tabular}

Comparison of growth pattern of children with asthma with normal children in the age group 5-10 years

50 children with asthma between the age of 5 and 10 years were compared with 50 normal children in the same age range. It was found that out of the total 100 children, 29 children (29\%) were having stunting and 5 children (5\%) had obesity.

Among 50 asthma children, 5 (10\%)had obesity whereas none were obese in the control group and this observation was found to be significant statistically ( $\mathrm{p}=0.028$ ). 20 of the 50 asthma children(40\%) had stunting as compared to 9 out of 50 normal children(18\%) and this was also significant $(\mathrm{p}=0.015)$

Table 2: BMI pattern of children with asthma and the control group between 5-10 years.

\begin{tabular}{|c|c|c|c|c|c|}
\hline \multirow{2}{*}{$\begin{array}{l}\text { BMI percentiles } \\
\text { according to WHO } \\
\text { growth chart }\end{array}$} & \multicolumn{2}{|c|}{$\begin{array}{l}\text { Asthma } \\
(n=50)\end{array}$} & \multicolumn{2}{|c|}{$\begin{array}{l}\text { Normal } \\
(n=50)\end{array}$} & \multirow[t]{2}{*}{ Total } \\
\hline & No: & $\%$ & No: & $\%$ & \\
\hline$>95$ th & 5 & 10 & - & & 5 \\
\hline Normal & 45 & 90 & 50 & 100 & 95 \\
\hline Total & 50 & 100 & 50 & 100 & 100 \\
\hline
\end{tabular}

(Association of obesity with asthma, $\mathrm{p}$ value $=0.028$, significant)

Table 3: height profile of children with asthma and the control group between 5-10 years

\begin{tabular}{|l|l|l|l|l|l|}
\hline $\begin{array}{l}\text { Height perentiles } \\
\text { according } \begin{array}{l}\text { Asthma } \\
\text { growth chart }\end{array}\end{array}$ & \multicolumn{2}{|l|}{$\begin{array}{l}\text { Normal } \\
(\mathbf{n = 5 0 )}\end{array}$} & \multirow{2}{*}{ Total } \\
\cline { 2 - 5 } & No: & $\mathbf{\%}$ & No: & \% & \\
\hline$<$ 3rd & 20 & 40 & 9 & 18 & 29 \\
\hline Normal & 30 & 60 & 41 & 82 & 71 \\
\hline Total & 50 & 100 & 50 & 100 & 100 \\
\hline
\end{tabular}

(Association of stunting with asthma, $\mathrm{p}$ value $=0.015$, significant)

Comparison of the growth pattern in children with asthma with normal controls in the age group $11-15$

The study had included 100 children between $11-15$ years age group which 50 children having asthma and 50 normal controls. It was found that out of the total 100 children, 16 children (16\%) were having stunting and 4 children (4\%) had obesity.

Out of 50 asthma children, 4 (8\%) had obesity as compared to 50 normal children in which none were obese and but the association with obesity with asthma in this age group was 
not found to be statistically significant $(p=0.072) .12$ of the 50 asthma children (24\%) had stunting as compared to 4 out of 50 normal children $(8 \%)$ and this also was significant. $(\mathrm{p}=0.029)$

Table 4: Height pattern of asthma and normal controls between 11-15 years

\begin{tabular}{|l|l|l|l|l|l|}
\hline \multirow{2}{*}{$\begin{array}{l}\text { Height percentiles } \\
\text { according to WHO } \\
\text { growth chart }\end{array}$} & \multicolumn{2}{|l|}{$\begin{array}{l}\text { Asthma } \\
\text { n=50 }\end{array}$} & \multicolumn{2}{|l|}{$\begin{array}{l}\text { Normal } \\
\text { n=50 }\end{array}$} & \multirow{2}{*}{ Total } \\
\cline { 2 - 5 } & No: & \% & No: & \% & \\
\hline$<3$ rd & 12 & 24 & 4 & 8 & 16 \\
\hline Normal & 38 & 76 & 46 & 92 & 84 \\
\hline Total & 50 & 100 & 50 & 100 & 100 \\
\hline
\end{tabular}

(Association of stunting with asthma, $\mathrm{p}$ value $=0.029$ significant)

\section{Table 5: BMI of asthma and normal children between 11-15} years

\begin{tabular}{|l|l|l|l|l|l|}
\hline \multirow{2}{*}{$\begin{array}{l}\text { BMI percentiles } \\
\text { according to WHO }\end{array}$} & \multicolumn{2}{l|}{$\begin{array}{l}\text { Asthma } \\
\text { growth chart }\end{array}$} & \multicolumn{2}{l|}{ Normal(n=50) } & \multirow{2}{*}{ Total } \\
\cline { 2 - 5 } & No: & \% & No: & \% & \\
\hline$>95$ th & 4 & 8 & - & - & 4 \\
\hline Normal & 46 & 92 & 50 & 100 & 96 \\
\hline Total & 50 & 100 & 50 & 100 & 100 \\
\hline
\end{tabular}

(Association of obesity with asthma $\mathrm{p}$ value-0.072, not significant)

\section{Comparison of the growth and severity of asthma}

Out of 100 asthma cases including 5-10 year age group and 11-15 year age group, 46 cases were newly diagnosed asthma cases and they were classified into mild asthma (intermittent and mild persistent together), moderate persistent and severe persistent asthma. 18 (39.1\%) came under category of mild asthma, 17 (36.9\%) under moderate persistent and $11(24 \%)$ under severe persistent asthma

Table 7: classification of newly diagnosed asthma cases based on severity

\begin{tabular}{|l|l|l|}
\hline Asthma & Number of cases $(\mathbf{n}=\mathbf{4 6})$ & $\mathbf{\%}$ \\
\hline Mild & 18 & 39.1 \\
\hline Moderate & 17 & 36.9 \\
\hline Severe & 11 & 24 \\
\hline Total & 46 & 100 \\
\hline
\end{tabular}

\section{Severity of asthma and BMI:}

3 out of 11 severe persistent asthma were obese $(27.3 \%)$ while none of moderate asthma and mild asthma were obese. The association of obesity with severe persistent asthma had $\mathrm{p}$ value of 0.013 showing statistical significance.

\begin{tabular}{|c|c|c|c|c|c|c|c|}
\hline Table 8 & BMI pa & ern & newly d & agno & d asthm & chil & \\
\hline BMI & Mild & & Modera & & Severe & & Total \\
\hline (WHO) & $\begin{array}{l}\text { No: } \\
(n=18)\end{array}$ & $\%$ & $\begin{array}{l}\text { No: } \\
(n=17)\end{array}$ & $\%$ & $\begin{array}{l}\text { No: } \\
(n=11)\end{array}$ & $\%$ & $(n=46)$ \\
\hline$>95$ th & - & - & - & - & 3 & 27.3 & 3 \\
\hline Normal & 18 & 100 & 17 & 100 & 8 & 72.7 & 43 \\
\hline Total & 18 & 100 & 17 & 100 & 11 & 100 & 46 \\
\hline
\end{tabular}

(Association of obesity with severe persistent bronchial asthma, $\mathrm{p}=0.006$, significant)

Out of the 11 severe persistent, 6 had stunting (54.5\%) as compared to 5 of 17 moderate persistent asthma children (29.4\%) and 1 of 18 mild asthma children (5.6\%) with $\mathrm{p}$ value of 0.013 showing that severe persistent asthma children had more stunting compared to mild to moderate persistent asthma

Table 9: Height pattern of newly diagnosed asthma children

\begin{tabular}{|c|c|c|c|c|c|c|c|}
\hline \multirow{2}{*}{$\begin{array}{l}\text { Height } \\
\text { (WHO) }\end{array}$} & \multicolumn{2}{|l|}{ Mild } & \multicolumn{2}{|c|}{ Moderate } & \multicolumn{2}{|l|}{ Severe } & \multirow{2}{*}{$\begin{array}{l}\text { Total } \\
(n=46)\end{array}$} \\
\hline & $\begin{array}{l}\text { No: } \\
(n=18)\end{array}$ & $\%$ & $\begin{array}{l}\text { No: } \\
(n=17)\end{array}$ & $\%$ & $\begin{array}{l}\text { No: } \\
(n=11)\end{array}$ & $\%$ & \\
\hline$<3 \mathrm{rd}$ & 1 & 5.6 & 5 & 29.4 & 6 & 54.5 & 12 \\
\hline Normal & 17 & 94.4 & 12 & 70.6 & 5 & 45.5 & 34 \\
\hline Total & 18 & 100 & 17 & 100 & 11 & 100 & 46 \\
\hline
\end{tabular}

(Association of stunting with severe persistent asthma, $\mathrm{p}$ value $=0.013$, significant)

\section{Comparison of growth and control of asthma:}

In this study we had 54 already diagnosed asthma cases on treatment. They were divided into well controlled, partially controlled and poorly controlled. 30 (56\%) were well controlled, $8(14 \%)$ were partially controlled and $16(30 \%)$ were poorly controlled.

Table 10: Classification of old cases of asthma based on treatment response

\begin{tabular}{|l|l|l|}
\hline Response to treatment & No: $(\mathbf{n}=\mathbf{5 4})$ & $\mathbf{\%}$ \\
\hline Well controlled & 30 & 56 \\
\hline Partially controlled & 8 & 14 \\
\hline Poorly controlled & 16 & 30 \\
\hline Total & 54 & 100 \\
\hline
\end{tabular}

\section{BMI pattern and control of asthma}

6 out of $16(37.5 \%)$ poorly controlled asthma children had BMI above 95th centile, while none of the well \& partially controlled asthma children had BMI above 95th centile. It could be concluded that obesity was more associated with poorly controlled asthma children as compared to partial and well controlled asthma children with p value of 0.006 .

\begin{tabular}{|c|c|c|c|c|c|c|c|}
\hline \multirow{2}{*}{$\begin{array}{l}\text { BMI } \\
\text { percentile(accor } \\
\text { ding to WHO } \\
\text { growth chart }\end{array}$} & \multicolumn{2}{|c|}{$\begin{array}{l}\text { Well } \\
\text { controlled }\end{array}$} & \multicolumn{2}{|c|}{$\begin{array}{l}\text { Partially } \\
\text { controlled }\end{array}$} & \multicolumn{2}{|c|}{$\begin{array}{l}\text { Poorly } \\
\text { controlled }\end{array}$} & \multirow{2}{*}{$\begin{array}{l}\text { Total } \\
(\mathrm{n}=5 \\
4)\end{array}$} \\
\hline & $\begin{array}{l}\text { No: } \\
(n=3 \\
\text { 0) }\end{array}$ & $\%$ & $\begin{array}{l}\text { No: } \\
(\mathrm{n}= \\
8)\end{array}$ & $\%$ & $\begin{array}{l}\text { No: } \\
(\mathrm{n}=1 \\
6)\end{array}$ & $\%$ & \\
\hline$>95$ th & - & 0 & - & 0 & 6 & $\begin{array}{l}37 . \\
5\end{array}$ & 6 \\
\hline Normal & 30 & $\begin{array}{l}10 \\
0\end{array}$ & 8 & $\begin{array}{l}10 \\
0 \\
\end{array}$ & 10 & $\begin{array}{l}62 . \\
5\end{array}$ & 48 \\
\hline Total & 30 & $\begin{array}{l}10 \\
0\end{array}$ & 8 & $\begin{array}{l}10 \\
0\end{array}$ & 16 & $\begin{array}{l}10 \\
0\end{array}$ & 54 \\
\hline
\end{tabular}

(Association of obesity with poorly controlled asthma, $\mathrm{p}$ value $=0.006$, significant)

\section{Linear growth and control of asthma}

11 out of the $16(68.7 \%)$ poorly controlled asthma, 4 out of 8 partially controlled asthma $(50 \%)$, and 5 out of 30 well controlled asthma (16.7\%) had stunting. On comparison, it was founds that stunting was significantly associated with poor control of asthma $(\mathrm{p}=0.002)$ 


\begin{tabular}{|c|c|c|c|c|c|c|c|}
\hline \multicolumn{8}{|c|}{ Table 12: linear growth pattern among children with asthma } \\
\hline \multirow{2}{*}{$\begin{array}{l}\text { Height } \\
\text { percentile } \\
\text { (according to } \\
\text { WHO } \\
\text { growth chart }\end{array}$} & \multicolumn{2}{|c|}{$\begin{array}{l}\text { Well } \\
\text { controlled }\end{array}$} & \multicolumn{2}{|c|}{$\begin{array}{l}\text { Partially } \\
\text { controlled }\end{array}$} & \multicolumn{2}{|c|}{$\begin{array}{l}\text { Poorly } \\
\text { controlled }\end{array}$} & \multirow{2}{*}{$\begin{array}{l}\text { Tota } \\
\text { l } \\
(n= \\
54)\end{array}$} \\
\hline & $\begin{array}{l}\text { No: } \\
(n= \\
\text { 30) }\end{array}$ & $\%$ & $\begin{array}{l}\text { No: } \\
(n=8)\end{array}$ & $\%$ & $\begin{array}{l}\text { No: } \\
(\mathrm{n}= \\
16)\end{array}$ & $\%$ & \\
\hline$<3 \mathrm{rd}$ & 5 & 16.7 & 4 & 50 & 11 & $\begin{array}{l}68 . \\
8\end{array}$ & 20 \\
\hline Normal & 25 & 83.3 & 4 & 50 & 5 & $\begin{array}{l}31 . \\
2\end{array}$ & 34 \\
\hline Total & 30 & 100 & 8 & 100 & 16 & $\begin{array}{l}10 \\
0\end{array}$ & 54 \\
\hline
\end{tabular}

(Association of stunting with poor asthma control, $\mathrm{p}$ value $=0.002$, significant)

\section{Discussion}

Comparison of growth pattern of children with asthma against healthy controls:

Obesity was found to be significantly associated with asthma in 5-10 years age group $(\mathrm{p}=0.028)$. Asthma and obesity have a considerable impact on public health and their prevalence has increased in recent years. Numerous studies have linked these disorders.

Study done by Figueroa et al, ${ }^{[7]}$ in which asthma children between 4-11 year age group were studied in U K, and showed significant association of obesity with asthma with $\mathrm{p}=0.002$. This study also concluded that asthma was more associated with obese children.

Most prospective studies show that obesity is a risk factor for asthma and have found a positive correlation between baseline body mass index and the subsequent development of asthma as well as the severity of asthma. Obesity is capable of reducing pulmonary compliance, lung volumes, and the diameter of peripheral respiratory airways as well as affecting the volume of blood in the lungs and the ventilation-perfusion relationship. Furthermore, the increase in the normal functioning of adipose tissue in obese subjects leads to a systemic pro inflammatory state, which produces a rise in the serum concentrations of several cytokines, the soluble fractions of their receptors, and chemokines. ${ }^{[8]}$

In 5-10 years age group, 20(40\%) had stunting and this was found to be statistically significant $(\mathrm{p}=0.015)$. In the study done by Mc Nicol et al, ${ }^{[9]}$ also, significant stunting was observed in children with asthma. Mc Murray et al, ${ }^{[10]}$ has described stunting in $37 \%$ of children with asthma.

In the 11-15 years age group, even though stunting was seen significantly associated with a asthma, obesity was not seen to have a significant association even though $8 \%$ of the children with asthma were obese whereas none was obese in the control group. The disparity seen in this age group could be due to the small sample size, because most of the studies have shown significant association of asthma with obesity as mentioned previously.

Growth variation in children based on severity :

In our study severe persistent asthma(54.5\%) had statistically significant stunting as compared to moderate asthma children $(29.4 \%)$ and mild persistent asthma children $(5.6 \%)$ with $\mathrm{p}$ value of 0.013 showing that severe persistent asthma children had more stunting compared to mild to moderate persistent asthma. Study done by Fallier's et al, ${ }^{[11]}$ found that nearly $70 \%$ severe asthma children had stunting. Children with severe asthma (27.3\%) had statistically significant obesity as compared to moderate and mild asthma children were none were obese with $p$ value of 0.013 showing that severe asthma children were more associated with obesity.

\section{Growth and Asthma Control:}

In our study we found that stunting was more associated with poorly controlled asthma children as compared to partial and well controlled asthma children with $\mathrm{p}$ value of 0.002 .

Similar study done by Nevell et al, ${ }^{[12]}$ also showed stunting is more seen in severe and poorly controlled asthma children as these children receive high doses of corticosteroids causing stunting.

Stunting occurs in asthma affected children probably because of malnutrition, chronic hypoxemia and also steroid treatment which is one of the main modality of treatment in asthma children which might interfere in osteoblastogenesis resulting in stunting.

Our study found that found that $37.5 \%$ of poorly controlled asthma children had BMI above 95th centile and none of the well \& partial controlled asthma children had BMI above 95th centile. Our study concluded that there was statistically significant association of obesity in poorly controlled asthma children $(\mathrm{p}=0.006)$.

\section{Conclusion}

Stunting and obesity are more seen in children with asthma compared to normal children. Children with severe asthma have more stunting and obesity compared to less severe forms of asthma. Stunting and obesity are significantly more in children whose asthma is poorly controlled.

\section{References}

1. GINA guidelines 2011

2. Murray AB, Fraser BM, Hardwick DF, Pirie GE Chronic Asthma and growth failure Lancet 1976;ii:197-198.

3. Kerrebijan KF, De Kroon JPM. Effect on height of corticosteroid therapy in asthmatic children. Arch Dis Child 1968;43:556-561

4. Stenius-Aarniala B, Poussa T, Kvarnstrom J, et al. Immediate and long term effects of weight reduction in obese people with Asthma: randomized controlled study.

5. BMJ 2000;320:827-32

6. Kaplan TA, Montana E. Exercise-induced bronchospasm in nonasthmatic obese children Paediatr Philia 1993;32:220-25

7. Patricia Gomes de Souza, Clemax Couto Sant'Anna, Maria de Fatima B, Pombo March. Quality of life in children with Asthma in Rio de Janeiro, Brazil. Indian J Pediatr (July 2013); 80 (7) : 544-548 
8. JJ Figueroa, Munoz, S Chenn, R J Rona. Assoc between obesity and Asthma in 4-11 year old children in UK. Thorax 2001;56:133-37.

9. Ford ES. The epidemiology of obesity and asthma. J Allergy Clin Immunol 2005;115:897-909

10. Mc Nicol KN , Williams HB . Spectrum of Asthma in children I Clinical and physiological components.BMJ 1973; 47:11.

11. Murray AB, Fraser BM, Hardwick DF, Peru GE . Chronic Asthma and growth failure in children. Lancet $1976 ; 2: 197-198$
12. Fallier CJ, Ian LS, Szentinvaneji J, Jorgensen J, Bukantz SC. Childhood Asthma and steroid therapy has influences on growth. Am J Dis child 1963 ; 105:127-37

13. Nevell RG, Mc Cowan C, Thomas G, Gombu IK. Asthma and growth - cause for concern? Asthma and growth in Tayside children. Am Hum Biol 1996 ; 23 : 323-31

Copyright: (C) the author(s), 2019. It is an open-access article distributed under the terms of the Creative Commons Attribution License (CC BY 4.0), which permits authors to retain ownership of the copyright for their content, and allow anyone to download, reuse, reprint, modify, distribute and/or copy the content as long as the original authors and source are cited.

How to cite this article: Jayasree P. Growth Pattern of School Going Children with Asthma: A Case Control Study. Asian J. Clin.Pediatr.Neonatol.2019;7(1):30-34.

DOI: dx.doi.org/10.21276/ajcpn.2019.7.1.8

Source of Support: Nil, Conflict of Interest: None declared. 